\title{
Comparing Behavioral Health Graduate Students in Spiritual and Religious Competence*
}

\author{
Jennifer S. Park ${ }^{1} \oplus$ \\ Colorado Christian University \\ Mark Newmeyer ${ }^{3}$ \\ Regent University
}

\author{
Kathleen Arveson ${ }^{2}$ \\ Regent University \\ Lee A. Underwood ${ }^{4}$ \\ Regent University
}

\begin{abstract}
When it comes to the integration of spirituality and religion within mental health training, standards remain ambiguous, particularly in non-religious affiliated institutions and individual practitioners. The aim of this study sought to examine the competence levels of mental health graduate students utilizing the Revised Spiritual Competence Scale II (SCS-R-II) and the Spiritual and Religious Competency Assessment (SARCA). Participants were recruited by contacting over 68 program directors of both Christian and secular accredited counseling, psychology, and social work schools in the United States and through the Counselor Education and Supervision Network Listserv and American Psychological Association of Graduate Students directory. 125 students with varying degrees of professed religious affiliation, completed the survey. Counselor trainees scored highest on both measures, yet without statistical significance. Students with very strong personal religious affiliation and attendees of Christian affiliated schools scored statistically higher on both measures. Findings indicated Christian institutions and trainees who professed very high Christian affiliation seemed to possess greater competence at integrating spiritual and religious constructs within mental health counseling. However, the results are limited due to sample size. Further, results pointed to convergent validity for the SCS-R-II and SARCA. Implications and future recommendations for behavior science educators and clinicians are discussed.
\end{abstract}

\section{Keywords}

Spirituality • Religion • SCS-R-II • SARCA • Spiritual Integration Competence

\footnotetext{
* The views expressed in this paper are those of the authors and not necessarily those of Colorado Christian University and Regent University.

1 Correspondence to: Jennifer S. Park (PhD). Colorado Christian University, Lakewood, CO. Email: jpark@ccu.edu

2 School of Psychology \& Counseling, Regent University, Virginia Beach, VA. Email: katharv@regent.edu

3 School of Psychology \& Counseling, Regent University, Virginia Beach, VA. Email: mnewmeyer@regent.edu

4 School of Psychology \& Counseling, Regent University, Virginia Beach, VA. Email: leeunde@regent.edu

Citation: Park, J. S., Arveson, K., Newmeyer, M., Underwood, L. A. (2018). Comparing behavioral health graduate students in spiritual and religious competence. Spiritual Psychology and Counseling, 3, 197-221. http://dx.doi.org/10.12738/spc.2018.3.2.0050
} 


\section{Davranışsal Sağlık Lisansüstü Öğrencilerinin Manevi ve Dinsel Yetkinlikler Açısından Karşılaştırılması}

\author{
Jennifer S. Park ${ }^{1} \odot$ \\ Colorado Christian University \\ Mark Newmeyer ${ }^{3}$ \\ Regent University
}

\author{
Kathleen Arveson ${ }^{2}$ \\ Regent University \\ Lee A. Underwood ${ }^{4}$ \\ Regent University
}

$\ddot{\mathrm{O} z}$

Ruh sağlığı eğitimi ile maneviyat ve din bütünleşmesinde standartlar, özellikle dini olmayan kurumlar ve bireysel uygulamacılar söz konusu olduğunda muğlak kalmaktadır. Bu çalışmanın amacı ruh sağlığı lisansüstü oğrencilerinin yeterlik düzeylerini Revize Edilmiș Ruhsal Yetkinlik Ölçeği II (SCS-R-II) ve Ruhsal ve Dinsel Yetkinlik Ölçümü'nü (SARCA) kullanarak incelemeyi amaçlamaktadır. Katılımcılara, Amerika Birleşik Devletleri'nde akredite olan, psikolojik danışmanlık, psikoloji ve sosyal çalışma alanlarındaki 68'in üzerinde gerek Hıristiyan, gerekse seküler yönelimli programların yöneticileri ile görüşülerek; Danışmanlık Eğitim ve Süpervizyon Ağı Listeleri ve Amerikan Psikoloji Derneği Lisansüstü Öğrenciler Dizini aracilığıyla ulaşılmıştır. Değişen düzeylerde dinsel bağlılıkları olduğunu bildiren 125 öğrenci ölçekleri tamamlamıştır. Danışmanlık öğrencileri, istatistiksel olarak anlamlı olmamakla birlikte her iki ölçümde de en yüksek düzeyleri sergilemişlerdir. Çok güçlü kişisel dini bağlllığı olan veya Hristiyan okullarına devam eden öğrenciler her iki ölçümde de istatistiksel olarak daha yüksek puanlar almışlardır. Bulgulara göre Hıristiyan kurumlarına kayıtlı olan veya çok yüksek düzeyde Hıristiyanlıkla ilişkili olduğunu ifade eden kursiyerler ruh sağlığı danışmanlığı kapsamında manevi ve dini yapıları bütünleştirme konusunda daha fazla yetkinliğe sahip görünmektedirler. Ancak, örneklem büyüklüğü nedeniyle sonuçlar sınırlıdır. Ayrıca, sonuçlar SCSR-II ve SARCA ölçeklerinin yakınsak geçerlilik düzeyinin yeterli olduğuna işaret etmektedir. Bulguların davranış bilimi eğitimcileri ve klinisyenleri için doğurguları ve geleceğe yönelik öneriler tartışılmıştır.

\section{Anahtar Kelimeler}

Maneviyat • Din • SCS-R-II • SARCA • Maneviyatı Bütünleștirme Yeterliliği 
As the diversity of the United States (U.S.) population increases (Adams, 2008; Hodge, 2007; Murphy, Park, \& Lonsdale, 2006; Pew Research Center, 2015), counselors are seeking to attend to a myriad of multicultural issues including race, ethnicity, socioeconomic status, sexual orientation, gender, and religion. With the influx of Eastern religions due to ongoing globalization, meditative practices have become quite popular in the United States and have heightened consciousness of mental health practitioners as well as the public's awareness about the value of spirituality (Pargament, 1999). The increasing diversity in cultures also parallels variety in spiritual expression within the United States (Barnes, Plotnikoff, Fox, \& Pendleton, 2000). Changing demographics have seen an increase in those affiliated with New Age, Buddhism, Hinduism, and Islam (Barrett, Kurian, \& Johnson, 2001). "Western concepts of mental health usually emphasize self-directedness and cooperativeness but neglect the crucial role of spiritual awareness and meaning based on self-transcendent values" (Cloninger, 2006, p. 2). Spiritual integration within the medical field aims at building trust and rapport with patients, but also plays a role in decision making for choice of therapy and interventions (Allen \& Crouch, 2005; Barnes et al., 2000). Mental health professionals have also emphasized the inclusion of spiritual and religious language and concepts to provide the best model of care, which would improve impact on clients. As counselors learn to grow professionally with the increasing diversity of spiritual orientations within the U.S. population, they require better preparation in dealing with unique spiritual practices. However, the specifics on how best to train mental health graduates towards competent and ethical practice are open for further discussion, research, and debate (Carlson, McGeorge, \& Toomey, 2014; Furness \& Gilligan, 2010; Gonsoriek, Richards, Pargament, \& McMinn, 2009; Murphy et al., 2006).

As spirituality and religious affiliation are integral to the well-being of individuals and communities within the U.S., counselors require awareness, knowledge, and skills (Sue, Arrendondo, \& McDavis 1992; Ratts, Singh, Nassar-McMillan, Butler, $\&$ McCullough, 2015) towards effectively integrating these constructs into therapy. Understanding what role spiritual and religious beliefs play in clients' worldview and identity formation is imperative towards building rapport and a strong therapeutic alliance, demonstrating respect for clients' traditions and values, accurately assessing contributing factors towards psychological duress, and collaborative efforts in formulating goals and implementing treatment. Mental health professionals who are reflective about how their beliefs may impact working with specific clients demonstrate competent and ethical practice in a multicultural world. Cashwell, Bentley, and Bigbee (2007) also purported the benefits of counselor spirituality on personal holistic wellness and the therapeutic relationship with clients. They recommended greater exposure and awareness of a variety of faith traditions. First, they suggested creating a spiritual place within the counselors' physical space by preparing ahead of time either through prayer or meditation before beginning the day. Then, the integration of 
spirituality into counseling reflects counselors' personal spirituality, which protects against compassion fatigue. Next, they emphasized the cultivation of mindfulness to increase endurance in remaining present with clients throughout the day and sustaining focus and finding joy. Mindfulness bolsters tolerance of intense emotions within counseling and allows counselors to explore such feelings with clients instead of feeling intimidated or fearful of them. Finally, they believed counselors may reflect upon perceived inadequacies more readily without severe criticism and grow in self-awareness and tolerance, therefore developing greater compassion towards self and clients. By increasing in "soulfulness, heartfulness, and mindfulness" (p. 67), counselors may gain a sacred understanding of the counseling process and the interconnectedness between counselor and client.

Hook et al. (2010) concluded that religious-based therapies were equally or more effective in alleviating depression, alcoholism, anxiety, anger, unforgiveness, and eating disorders as secular modalities. However, they pointed to the paucity of literature on outcome research for specifically religious and spiritual modalities. Moreira-Almeida, Koenig, and Lucchetti (2014) asserted the benefits of including a spiritual history during the assessment process, emphasizing how religion and spirituality are multidimensional constructs. They concentrated on five general principles including being cognizant of ethical boundaries, utilizing a person-centered approach, awareness of countertransference, respectful curiosity and openness to patients' beliefs, and readily self-disclosing in building a working alliance. Further, they recommend approaching the spiritual history after rapport has been established rather than delving into personal values from the start. Cheston and Miller (2011) noted numerous commonalities between praying and counseling, especially in enhancing self-awareness and focusing on releasing tension. They distinguish between prayers used outside of clinical sessions from those overtly incorporated into sessions and caution against utility without explicit assessment of clients' spiritual orientation. For individuals who are struggling with a crisis of faith, prayer may fuel greater anger towards God. Other common spiritual interventions are meditation, spiritual imagery, and spiritual direction (Richards, Bartz, \& O'Grady, 2009). Since a significant percentage of religious persons in the U.S. identify themselves as Christian (Gallup, 2014), in the UK as well (Pentaris, 2012), clients may possess a set of expectations from professional Christian therapists congruent with their prior experiences within church settings (Garzon, Worthington, Tan, \& Worthington, 2009). This further complicates working alliance having certain preconceptions of how practitioners will attend to and incorporate spiritual/religious topics in counseling. When clients' expectations are unmet, negative outcomes may arise, such as early termination (Hodge \& Limb, 2010; Horvath \& Luborsky, 1993). For example, the explicit references to Scripture may not be standard practice for the majority of professional Christian clinicians. Nonetheless, Walker, Gorsuch, and Tan (2004) purported a rising trend in Scripture 
and prayer incorporation among a diverse group of therapists. However, frequency and utility of these practices remain questionable.

Despite the rising attention on spirituality and religion in counseling, the majority of practitioners still express discomfort about addressing such issues in practice (Adams, 2008; Cashwell \& Young, 2011). Reasons include fear of making mistakes, of imposing personal values, lack of knowledge regarding interventions and assessments, and biases on the part of counselors (Cashwell \& Young, 2011). Although research on spirituality and religion has burgeoned in the last two decades, there is still much to be done in the area of counseling, psychology, and social work education, training, and perceived levels of competence in the integration of spirituality into practice (Adams, 2008; Barker, 2007; Brown et al., 2013; Cashwell \& Young, 2011; Dailey, Robertson, \& Gill, 2015). As mental health practitioners acknowledge the significance of religion and spirituality in positive outcomes for clients (Bilgrave \& Deluty, 1998; Knox, Catlin, Casper, \& Schlosser, 2005), numerous studies repeatedly call attention to the dearth of literature on levels of awareness of spiritual competence and what training entails as well as methods for evaluation (Adams, 2008; Bilgrave \& Deluty, 1998; Pelletier \& McCall, 2005). Certain content areas relating to specific spiritual phenomena and diagnosis appear to be lacking among spiritually competent counselors (Dailey et al., 2015). Other studies have focused on counselor and psychology graduate programs (Burke et al., 1999; Cashwell et al., 2013; Cates, 2009; Crook-Lyon et al., 2012), so the inclusion of the social work branch will better inform mental health education and what differences may translate across the various mental health professions. As a result, the gap between perceived importance of religious and spiritual integration in counseling and actual practice will potentially diminish, thus increasing the well-being of clients through a holistic approach.

\section{Purpose}

The purpose of this study is to investigate the relationship between type of mental health graduate student and competence with addressing spirituality and/or religion during counseling for mental health issues. To date, few studies have compared counseling, psychology, and social work students' competence to integrate spirituality within counseling (Adams, 2008; Oxhandler \& Pargament, 2014). Another purpose is to compare two different instruments measuring spiritual competence in counseling among the three mental health fields listed above.

The measures used will further elucidate how mental health graduate students incorporate spirituality and religion into their counseling and what differences are present between the various behavioral health practice fields. In addition, perception of competence in integrating spiritual and religious issues into counseling will point to strengths and weaknesses in training programs across counseling, psychology, and social work fields. 


\section{Method}

Research on spirituality and religion within behavioral science has been a controversial topic. However, this topic deserves ongoing attention due to reported prevalence of the client population's growing diversity and accompanying desire for counselors to address topics surrounding spiritual and religious beliefs and practices. Although the literature has burgeoned in this arena in the past few decades, the call for clarification and timely updates is necessary (Adams, 2008; Cashwell \& Young, 2011; Fluellen, 2007; Robertson, 2008).

\section{Research Questions}

The following questions were designated for this study: (i) RQ1: Is there a relationship between perceived competence of spiritual integration and type of mental health graduate student (counseling, psychology, or social work) after controlling for personal and institutional religious affiliation as measured by the SARCA? (ii) RQ2: Is there a relationship between perceived competence of spiritual integration and type of mental health graduate student (counseling, psychology, or social work) after controlling for personal and institutional religious affiliation as measured by the SCS-R-II? (iii) RQ3: Is there a significant relationship between type of mental health graduate student on the combined DV of spiritual and religious competence in counseling after controlling for personal and institutional religious affiliation as measured by the SARCA and the SCS-R-II? (iv) RQ4: Do scores on the SARCA correlate with scores on the SCS-R-II? The associated hypotheses were the following: (i) Yes, there is a significant relationship between perceived competence of spiritual integration and type of mental health graduate student (counseling, psychology, or social work) after controlling for personal and institutional religious affiliation as measured by the SARCA. (ii) Yes, there is a significant relationship between perceived competence of spiritual integration and type of mental health graduate student (counseling, psychology, or social work) after controlling for personal and institutional religious affiliation as measured by the SCS-R-II. (iii). Yes, there is a significant relationship between type of mental health graduate student on the combined DV of spiritual and religious competence in counseling after controlling for personal and institutional religious affiliation as measured by the SARCA and the SCS-R-II. And (iv). Scores on the SARCA will have a positive correlation with the scores on the SCS-R-II demonstrating convergent validity.

\section{Research Design}

The research method used in this study was a correlational design. This study aimed to discover the relationship between spiritually competent practice and mental health graduate student across social work, counseling, and psychology. 


\section{Population and Sampling}

Participants in the study were mental health graduate students in an accredited counseling, psychology, or social work master's or doctoral program from universities across the United States. Sampling a variety of geographical regions sought to bolster generalizability and random selection. Counseling and social work students obtain licensure after achieving master's degrees versus psychologists, who must earn doctoral degrees for licensure. In order to retain moderate levels of competence, one requirement for participation included completion of practicum or internship. Participants may or may not have been licensed as mental health practitioners due to varying requirements by profession, and possessed minimal to extensive experience working in the field of human services.

Invitation letters were individually sent out electronically to over 68 directors and/or professors of mental health graduate programs in the U.S. located through the directory for accredited programs of the Council on Social Work Education (http://www.cswe.org/Accreditation/Accredited-Programs.aspx), of the Council for Accreditation of Counseling and Related Programs (http://www.cacrep.org/ directory/), and of the American Psychological Association (http://apps.apa.org/ accredsearch/) and through collegial networking. Further, students were contacted via email through the Counselor Education and Supervision Network listserv (CESNET) and the American Psychological Association of Graduate Students listserv (APAGS). Graduate students of psychology responded least, so an additional invitation through the Christian Association of Psychological Studies (CAPS) was emailed to the director, who agreed to pass along to student members. Participants were then contacted by program directors and professors via email with the researcher's invitation letter. The email included an initial informed consent form explaining the purpose, benefits, and risks of the study and then provided a link to the survey webpage if individuals chose to participate. In order to achieve statistical power in this study (Cohen, 1988), a minimum of 100 participants are required.

\section{Instrumentation}

Spiritual and Religious Competency Assessment (SARCA). The SARCA was developed by Fluellen (2007) and is a 34-item measure, which assesses perception of integration of spirituality and religion in counseling supervisees and was based upon the ASERVIC competencies (2009). Four experts reviewed the initial instrument, and results of factor analysis established one factor [unspecified in the study (Fluellen, 2007)]. The experts all possessed doctoral degrees and expertise in psychology, spirituality, and supervision. Cronbach's alpha for the SARCA is high at .909. Fluellen (2007) administered the SARCA to psychology students from all states in the U.S. The items utilize a 6-point scale (strongly disagree, disagree, slightly disagree, 
slightly agree, agree, and strongly agree). Certain positively worded items are scored with strongly disagree $=1$ up to strongly agree $=6$ versus other negatively worded items scored strongly disagree $=6$ to strongly agree $=1$. For example, question one is, "I include assessments (written and/or oral) of religious and spiritual beliefs in my work with clients." Fluellen (2007) included a scoring protocol for the SARCA specifying which question numbers were positively versus negatively worded. The lowest score is a 34, and highest 204.

Revised Spiritual Competency Scale II (SCS-R-II). The SCS-R-II is a 21-item inventory measuring spiritual competence in counseling (Robertson, 2011) and aligns with the Spiritual Competencies of the Association for Spiritual, Ethical, and Religious Values in Counseling (ASERVIC, 2009). The SCS-R-II is a revised edition of the Spiritual Competency Scale (SCS; Robertson, 2010), which included six categories: Culture and Worldview, Counselor Self-Awareness, Human and Spiritual Development, Communication, Assessment, and Diagnosis and Treatment and is useful to "inform curriculum development, as a measure of training outcomes, and as a tool for the certification of spiritually competent counselors (abstract). The SCS-RII may serve to "establish a baseline for competency, as a benchmark for certification programs, as an assessment of student learning, and as a tool to understand where individuals are in the process of becoming spiritually competent" (Dailey et al., 2015, p. 25). The same six factors loaded from the SCS on the SCS-R-II accounting for $61 \%$ of the variance. Internal consistency of the SCS-R-II is high (Cronbach's alpha $=.84$ ). A cut-off score of 105 demonstrates spiritual competence (Dailey et al., 2015). The participants were asked to rate on a 6-point scale (low agreement, mid agreement, high agreement, low disagreement, mid disagreement, high disagreement) their opinions on including spirituality and religion in clinical practice. Scoring for the scale is as follows: Low Agreement $=4$, Mid-range Agreement $=5$, High Agreement $=6$, Low Disagreement $=3$, Mid-range Disagreement $=2$, High Disagreement $=1$ ) . Question one on the SCS-R-II is "Counselors who have not examined their spiritual/ religious values risk imposing those values on their clients."

\section{Procedure}

After receiving permission from authors of the measuring instrumentation and approval from the university's Human Subjects Review Committee (HSRC) for the Use of Human Subjects, a list of directors and professors of accredited counseling (CACREP), psychology (APA), and social work (CSWE) programs was accessed. The invitation to participate included an introductory email with the informed consent, which provided a brief description about the purpose and methodology of the study, risks and benefits of participation, contact information for the researcher regarding any inquiries, and the availability to access findings upon completion of the study. 
The individuals who chose to continue were directed to a link to a confidential online survey webpage. Their consent was demonstrated by clicking the link to proceed with the survey, which included a demographic survey, the SCS-R-II and the SARCA. Participants were permitted to withdraw from the study at any point and time before completing and submitting all measures.

\section{Predictor and Criterion Variable Description}

For the analyses of covariance (ANCOVA), the predictor variable was type of mental health graduate student: counseling, psychology, or social work. The two criterion variables were results on Spiritual and Religious Competency Assessment (SARCA) and Revised Spiritual Competency Scale-II (SCS-R-II) respectively. For the multivariate analysis of covariance (MANCOVA), the predictor variable was the type of mental health graduate student and criterion variable the combined scores on the SARCA and SCS-R-II. For the bivariate correlation, the predictor variable was total score on the SARCA and criterion variable was total score on the SCS-R-II.

\section{Statistical Analyses}

In this study, two separate analyses of covariance were conducted with certain demographic characteristics as covariates: personal and institutional religious affiliation. Further, a multivariate analyses of covariance was conducted with both covariates. This study also utilized a bivariate correlation, which compared the results on the SARCA and the SCS-R-II. Additionally, two additional analyses of variance compared the differences between strength of religious affiliation and scores on the SARCA and the SCS-R-II.

\section{Results}

Findings indicated that counseling, psychology, and social work students performed somewhat similarly on the SCS-R-II and the SARCA. However, the mean for counseling students was highest in both instruments, more so on the SARCA than the SCS-R-II.

\section{Data Cleaning}

A total of 178 students began the survey. 18 completed the demographic survey, but chose not to proceed with the SCS-R-II, and 20 participants skipped the entire SARCA, so those 38 were removed from the sample. An additional 15 did not meet the study's criteria, so were also negated from the pool leaving the total number at $125(\mathrm{~N}=125)$. The mean was imputed for any values missing from remaining questions on the SCS-R-II [(specifically Q1, 2, 3, 9, and 18 were missing one value, 
and Q10 and 13 were missing two) and the SARCA (specifically Q1, 2, 8, 14, 15, 16, $19,21,23,29,30,32$, and 33 were missing one value, and Q4, 27, 28, 31, and 34 were missing two)] in order to compute total scores for both measures.

\section{Descriptive Statistics}

The majority of participants were master's level students (67.2\%) attending a private university (63.2\%) on campus $(77.6 \%)$, who were female $(79.2 \%)$, Caucasian (74.4\%), and under the age of $32(68.0 \%) .84 \%$ had practiced less than 5 years in the mental health field, and most were unlicensed as counselors, psychologists, or social workers (89.6\%). Approximately half (52.8\%) ascribed to a Christian denomination with $19.2 \%$ choosing other, and $12 \%$ identifying as Catholic. $80.8 \%$ professed a strong personal spiritual/religious affiliation. $70.4 \%$ of participants indicated their spirituality/religion influenced their career choice.

\section{Reliability Testing of the SARCA and SCS-R-II}

In order to determine the internal consistency of the sample, the data was analyzed for each measure of perceived competence of spiritual and religious integration in counseling. Reliability for both instruments was high with Cronbach's alpha for the SARCA at .92 and for the SCS-R-II at .89, which are comparable to the studies by Fluellen (2007) and Dailey et al. (2015) respectively; thus suggesting that participants approached the measures in a manner consistent with other studied populations.

\section{Hypotheses}

Hypothesis 1. Hypothesis 1 was not supported. A one-way analysis of covariance (ANCOVA) was planned. The independent variable, type of mental health graduate student, included three categories: counseling, psychology, and social work. The dependent variable was competence of spiritual integration as measured by the total score on the SARCA. The covariates were personal and institutional religious affiliation. A preliminary analysis evaluating the homogeneity-of-slopes assumption indicated that the relationship between the institutional religious affiliation covariate and the dependent variable did differ significantly as a function of the independent variable, $F(2,113)=4.04, M S E=1115.31, p=.02$, partial $\eta^{2}=.07$. Therefore, an ANCOVA could not be conducted using this covariate. Instead, an additional oneway between-subjects analysis of variance (ANOVA) was conducted to examine the differences in SARCA scores based on institutional religious affiliation. Results indicated a significant difference between institutional religious affiliations, $F(2,117)$ $=7.89, p=.001$, partial $\eta^{2}=.12$. Post hoc analyses using Tukey HSD revealed a significant difference between graduate institutions with Christian affiliations ( $M=$ $162.98, S D=15.39)$ and no affiliation $(M=149.78, S D=19.27)$. There were no 
significant differences between Catholic affiliation $(M=156.15, S D=15.54)$ and Christian or no affiliation.

For the personal religious affiliation covariate, the preliminary analysis evaluating the homogeneity-of-slopes assumption indicated that the relationship between the covariate and the dependent variable did not differ significantly as a function of the independent variable, $F(2,113)=2.57, M S E=709.75, p=.08$, partial $\eta^{2}=.04$. The ANCOVA was not significant, $F(2,120)=2.77, M S E=890.22, p=.07$, partial $\eta^{2}=.04$, indicating no significant differences between type of graduate student and SARCA scores while controlling for personal religious affiliation.

Table 1

Means and Standard Deviations in SARCA Scores According to Type of Student and Affiliation for Hypothesis 1

\begin{tabular}{lccc}
\hline \multicolumn{1}{c}{ Variable } & $n$ & $M$ & $S D$ \\
\hline Type of Student & & & \\
Counseling & 62 & 160.36 & 19.24 \\
Psychology & 22 & 155.68 & 14.48 \\
Social Work & 41 & 151.90 & 17.30 \\
& & & \\
Affiliation of Institution & & & 15.54 \\
Catholic & 13 & 156.15 & 15.39 \\
Christian & 56 & 162.98 & 19.27 \\
No Affiliation & 51 & 149.78 & \\
\hline
\end{tabular}

Hypothesis 2. Hypothesis 2 was not supported. A one-way analysis of covariance (ANCOVA) was planned. The independent variable, type of mental health graduate student, included three categories: counseling, psychology, and social work. The dependent variable was competence of spiritual integration as measured by the total score on the SCS-R-II. The covariates were personal and institutional religious affiliation. A preliminary analysis evaluating the homogeneity-of-slopes assumption indicated that the relationship between the institutional religious affiliation covariate and the dependent variable did differ significantly as a function of the independent variable, $F(2,113)=5.42, M S E=751.13, p=.01$, partial $\eta^{2}=.09$. Therefore, an ANCOVA could not be conducted using this covariate. Instead, an additional oneway between-subjects analysis of variance (ANOVA) was conducted to examine the differences in SCS-R-II scores based on institutional religious affiliation. Results indicated a significant difference between institutional religious affiliations, $F(2,117)=$ $9.64, p<.001$, partial $\eta^{2}=.14$. Post hoc analyses using Dunnett $\mathrm{C}$ revealed a significant difference between graduate institutions with Christian affiliations $(M=109.79, S D=$ 9.59) and no affiliation $(M=99.88, S D=13.33)$. There were no significant differences between Catholic affiliation $(M=103.00, S D=13.64)$ and Christian or no affiliation.

For the personal religious affiliation covariate, the preliminary analysis evaluating the homogeneity-of-slopes assumption indicated that the relationship between the covariate and the dependent variable did not differ significantly as a function of the 
independent variable, $F(2,113)=.34, M S E=46.71, p=.72$, partial $\eta^{2}=.01$. The ANCOVA was not significant, $F(2,120)=1.59, M S E=248.74, p=.21$, partial $\eta^{2}=$ .03 , indicating no significant differences between type of graduate student and SCSR-II scores while controlling for personal religious affiliation.

Table 2

Means and Standard Deviations in SCS-R-II Scores According to Type of Student and Affiliation for Hypothesis 2

\begin{tabular}{lccc}
\multicolumn{1}{c}{ Variable } & $n$ & $M$ & $S D$ \\
\hline Type of Student & & & 11.62 \\
Counseling & 61 & 106.77 & 13.87 \\
Psychology & 22 & 105.41 & 12.94 \\
Social Work & 41 & 102.29 & \\
& & & 13.64 \\
Affiliation of Institution & & & 9.59 \\
Catholic & 13 & 103.00 & 13.33 \\
Christian & 56 & 109.79 & 99.88 \\
No Affiliation & 51 & & \\
\hline
\end{tabular}

Table 3

Univariate Effects for Hypothesis 1-2

\begin{tabular}{lccccc}
\hline \multicolumn{1}{c}{ Dependent Variables } & $d f$ & $d f$ error & $F$ & Group & $p$ \\
\hline SARCA scores & 2 & 120 & 2.77 & $\begin{array}{l}\text { Counseling } \\
\text { Psychology } \\
\text { Social Work }\end{array}$ & .94 \\
& & & & Counseling \\
SCS-R-II Scores & 2 & 120 & 1.59 & $\begin{array}{l}\text { Psychology } \\
\text { Social Work }\end{array}$ & .07 \\
& & & & Social & \\
\hline
\end{tabular}

Hypothesis 3. Hypothesis 3 was not supported. A one-way multivariate analysis of covariance (MANCOVA) was planned to determine group differences in type of mental health graduate student on measures in competence of spiritual integration while controlling for personal and institutional religious affiliation. Preliminary Box's $M$ test was not significant, indicating that the homogeneity of variancecovariance assumption was fulfilled. However, a preliminary MANCOVA indicated that the relationship between the institutional religious affiliation covariate and the combined dependent variable did differ significantly as a function of the independent variable, Wilk's Lambda $=.86, F(4,224)=4.25, p=.002$, multivariate partial $\eta 2=$ .07. Therefore, a MANCOVA could not be conducted using this covariate.

Instead, an additional MANOVA was conducted to explore the effect of institutional religious affiliation on perceived competence of spiritual integration as measured by SARCA and SCS-R-II scores. Results from Box's test did not indicate a violation of homogeneity of variance-covariance; thus Wilks' Lambda was utilized to interpret multivariate results. There was a statistically significant difference found between groups on the combined dependent variables, Wilks' Lambda $=.82, F(4,232)=6.12$, $p<.001$, partial $\eta 2=.10$. 
When the results for the two dependent variables were considered separately using a Bonferroni adjusted alpha level of 0.025 , both DVs reached statistical significance: SARCA scores, $F(2,117)=7.89, p=.001$, partial $\eta 2=.12$, and SCS-R-II scores, $F$ $(2,117)=9.64, p<.001$, partial $\eta 2=.14$. Results indicated that the Christian group (SARCA, $M=162.98, S D=15.39$; SCS-R-II, $M=109.79$, $S D=9.59$ ) had significantly higher scores on both scales when compared to the Catholic group (SARCA, $M=$ $156.15, S D=15.54$; SCS-R-II, $M=103.00, S D=13.64$ ) and the No Affiliation group (SARCA, $M=149.78, S D=19.27$; SCS-R-II, $M=99.88, S D=13.33$ ).

For the personal religious affiliation covariate, the preliminary analysis indicated that the relationship between the covariate and the combined dependent variable did not differ significantly as a function of the independent variable, Wilks' Lambda $=.94, F(4,224)=1.92, p=.11$, multivariate partial $\eta 2=.03$. Thus, a MANCOVA to examine group differences based on graduate program in competence of spiritual integration while controlling for personal religious affiliation was conducted. MANCOVA results revealed that there was not a significant difference in graduate program on the combined dependent variable, Wilks' Lambda $=.95, F(4,238)=1.56$, $p=.19$, multivariate partial $\eta 2=.03$.

Table 4

Multivariate Effects (at $p<.05)$ for Hypothesis 3

\begin{tabular}{lccccc}
\multicolumn{1}{c}{ Variables } & Wilk's Lambda & $F$ & $d f$ & Error $d f$ & $p$ \\
\hline $\begin{array}{l}\text { Type of student } \\
\text { (counseling, psychology, social work) }\end{array}$ & 0.94 & 1.92 & 4 & 224 & .11 \\
$\begin{array}{l}\text { School affiliation } \\
\text { (Catholic, Christian, } \\
\text { none) }\end{array}$ & & & & & \\
\end{tabular}

*Dependent variables include scores on the SARCA and the SCS-R-II.

$* * p<.001$

Hypothesis 4. Hypothesis 4 was supported. A Pearson correlation coefficient was conducted to evaluate the relationship between the two spiritual integration competence measures SARCA and SCS-R-II. Results indicated a strong, positive correlation, $r=$ $.46, n=125, p<.001$. Further, a bivariate linear regression confirmed this relationship and indicated a strong predictive relationship between SARCA and SCS-R-II scores, $F(1,124)=33.36, p<.001$. The effect size was large, $R^{2}=.21$, indicating that $21 \%$ of the variance in SARCA scores can be accounted for by SCS-R-II scores.

Table 5

Pearson Correlation between the SARCA and SCS-R-II $(\mathrm{N}=125)$ for Hypothesis 4

\begin{tabular}{llll}
\hline \multicolumn{1}{c}{ Model } & $r$ & $N$ & Sig \\
\hline SARCA and SCS-R-II scores & .46 & 125 & $.001 *$ \\
\hline$* p<.001$ & & &
\end{tabular}


Table 6

Regression Results for Predicting SCS-R-II scores for Hypothesis 4

\begin{tabular}{lcccc}
\hline \multicolumn{1}{c}{ Model } & $R$ & $R 2$ & ANOVA & Sig \\
\hline SARCA scores & .05 & .21 & .348 & $.001 *$ \\
\hline$* p<.001$ & & & &
\end{tabular}

\section{Exploratory Analyses}

A one-way between-subjects analysis of variance (ANOVA) was conducted to examine the differences in SCS-R-II scores based on strength of personal religious affiliation. Results indicated a significant difference between degrees of personal religious affiliation, $F(2,121)=10.60, p<.001, \eta^{2}=.15$. Post hoc analyses using Tukey HSD revealed a significant difference between students who felt very strongly about their religious affiliation $(M=110.20, S D=9.24)$ and those who felt strongly $(M=102.91, S D=12.57)$. There was also a significant difference between those who felt very strongly about their spirituality and those that did not feel strongly ( $M=$ $98.10, S D=12.48)$.

A one-way between-subjects analysis of variance (ANOVA) was conducted to examine the differences in SARCA scores based on strength of personal religious affiliation. Results indicated a significant difference between degrees of personal religious affiliation, $F(2$, $121)=10.53, p<.001, \eta^{2}=.15$. Post hoc analyses using Tukey HSD revealed a significant difference between students who felt very strongly about their religious affiliation $(M=$ $163.72, S D=16.65)$ and those who felt strongly $(M=154.11, S D=16.67)$. There was also a significant difference between those who felt very strongly about their spirituality and those that did not feel strongly $(M=144.81, S D=17.51)$.

Table 7

Means and Standard Deviations in SCS-R-II and SARCA Scores According to Strength of Religious Affiliation

\begin{tabular}{lccc}
\hline \multicolumn{1}{c}{ Variable } & $n$ & $M$ & $S D$ \\
\hline Strength of R/S affiliation & & & \\
SCS-R-II & & & 9.24 \\
$\quad$ Very strong & 54 & 110.20 & 12.57 \\
Strong & 47 & 102.91 & 12.48 \\
& 21 & 98.10 & \\
Not strong & & & 16.65 \\
& & & 16.67 \\
SARCA & 54 & 163.72 & 17.51 \\
$\quad$ Very strong & 47 & 154.11 & \\
$\quad$ Strong & 21 & 144.81 & \\
$\quad$ Not strong & & & \\
\hline
\end{tabular}


Table 8

Univariate Effects for Strength of Affiliation

\begin{tabular}{lccccc}
\hline \multicolumn{1}{c}{ Dependent Variables } & $d f$ & $d f$ error & $F$ & Group & $p$ \\
SARCA scores & 2 & 121 & 10.53 & $\begin{array}{c}\text { Very Strong } \\
\text { Strong } \\
\text { Not Strong }\end{array}$ & $.001^{*}$ \\
& & & & & Very Strong \\
SCS-R-II Scores & 2 & 121 & 10.60 & Strong & $.001 *$ \\
& & & & Not Strong & \\
\hline
\end{tabular}

$* p<.001$

\section{Discussion}

This study's findings indicate that mental health graduate students who attend Christian affiliated institutions demonstrate a higher measure of competence in integrating spirituality and/or religion in counseling according to both measures: SARCA and SCS-R-II. This robust finding matches previous studies (Cates, 2009; Fluellen, 2007) in supporting similar outcomes without the distinction of Christian versus Catholic or no affiliation. Since faculty at religiously affiliated institutions commonly are often required to practice a congruent faith with the spiritual creed of the school, one may assume an increased mandate by the institution to integrate spirituality and religion within said education. These findings are congruent with a study by Carlson, McGeorge, and Toomey (2014) reporting that increased levels of training in spiritual integration for family therapy students at religiously affiliated school increased spiritual self-exploration. Conversely, students from secular institutions had lower levels of exploration with higher training. This suggests that secular students, who do not have a professed investment in religion, may not feel comfortable discussing such topics or are not encouraged to explore this dimension. Institutions with religious affiliations spend more time addressing ethical parameters on how clinicians should not impose personal values (Carlson et al., 2014) while supporting students in their reflection upon and commitment to their own beliefs. Clearly Christian mental health graduate programs supersede secular counseling, psychology, and social work schools in qualifying trainees to integrate spirituality competently within practice, but the mechanisms by which this is accomplished lack empirical evidence.

Fluellen (2007) noted that participants who attended a religiously affiliated institution scored significantly higher on the SARCA "(affiliated school mean = 158.96, non-affiliated school mean $=148.177)$ " (p. 60). The findings of this study demonstrated a larger gap in SARCA mean scores between participants from mental health graduate schools with Christian affiliation versus those without any religious affiliation. This presents a serious concern for such a discrepancy and deserves attention in future research. According to this survey data, the vast amount of people seeking graduate training in the helping fields $(70 \%)$ do so because of prior and/ 
or current religious and spritual formation. As a result, attention to training human caregivers in this area is a professional disconnect that also must be addressed.

Professing a personal spiritual and religious affiliation was not found to be significantly related to higher scores on the SARCA and SCS-R-II. However, additional exploratory analyses comparing strength of religious affiliation were significant in that students who self-identified "very strongly" with their personal faith scored higher on both the SARCA and SCS-R-II than those that self-identified as "strongly" and "not strongly" believing in their faith. Furthermore, only trainees who affiliated "very strongly" exceeded the cutoff score on the SCS-R-II. This aligns with Robertson (2008) on the original Spiritual Competency Scale (SCS) scores where she reported significant differences based upon strength of religious affiliation, which was titled "level of religiousness" (p. 175). In addition, Fluellen (2007) reported a significant correlation between personal spirituality/religion and spiritual/religious competence ( $p$ 68). Similarly, Thorpe (2001) purported a significant relationship between social work students who "reported significance of religious or spiritual beliefs and perception of competency" (p. 68). One may query the evolution of what personal spirituality and religion mean to individuals, yet those who are firm in their beliefs are more likely to incorporate spirituality in the practice of counseling. Because the strength of religious affiliation was measured from a question on the demographic survey, these results may be viewed with caution.

Ethical considerations may also play a role in how individual practitioners incorporate their belief systems in the profession of counseling as the ACA Code of Ethics (2014) states professionals are "to avoid imposing - their own values, attitudes, beliefs, and behaviors" on clients while respecting client and trainee diversity (A.4.b). With the awareness of our increasingly litigious society (Bernard \& Goodyear, 2009), mental health graduate students are likely to be cautious when broaching spiritual and religious topics. However, trainees that firmly profess their religious affiliation seemingly are more inclined and adept at including spirituality within the counseling process as those contribute to shaping one's purpose, identity, and worldview (Cloninger, 2006; Frankl, 1955; Furman, Benson, \& Canda, 2008; Hull, Suarez, Sells, \& Miller, 2013; Myers \& Williard, 2003; Pelletier \& McCall, 2005; Tan, 2005).

Robertson (2008) also found that participants more familiar with the ASERVIC Spiritual Competencies (2005) scored higher on the SCS (p. 179). This correlates with the findings of the present study in that counseling students scored highest on the SCSR-II as they would have more immediate access and introduction to the ASERVIC (2009) competencies than psychology and social work students. Again, ASERVIC is a branch of the American Counseling Association (ACA). Counselors also possess a professional identity founded on a developmental perspective, which incorporates 
spiritual development (Chandler et al., 1992). In a recent study by Reiner and Dobmeier (2014), certain competencies were more likely to be covered (Competencies 10, 11, and 14) in counseling graduate experiences than others (Competencies 6 and 14) as well as specific topics related to spirituality: wellness, hope, meaning, and forgiveness. However, most training in religious and spiritual integration came from "extension activities" (p. 203) beyond graduate school, which highlights the need for increased training on the ASERVIC competencies and spirituality in general.

Although 95\% of psychology students in Fluellen's (2007) study self-reported praying weekly (p. 63), this researcher found minimal participation from the same pool in comparison to counseling and social work students. Perhaps psychology graduate students are still operating on the foundation of leaning towards more scientific-based methods, which have traditionally shied away from spiritual and religious inclusion (Adams, 2008; Hook et al., 2010; Pargament, 1999; Richards \& Bergin, 1997; Shafranske, 2002; Zinnbauer \& Pargament, 2000). Cates (2008) found that psychologists were aware of their spirituality, yet did not include that understanding in clinical practice (p. 89). He also discovered that counselors scored higher on the majority of domains of spiritual competence than psychologists (p. 90). These findings point to a distinction in counselors' versus psychologists' professional identity; although both have ethical guidelines addressing multiculturalism (ACA, 2014; APA, 2010), counselors appear to have a greater emphasis on diversity, and in turn spirituality and religion, as demonstrated in the CACREP $(2009,2016)$ standards. Although counseling is the newer profession between the two, it has historically included spirituality earlier than the field of psychology.

Social work students scored least on the SCS-R-II and SARCA among the three types of mental health graduate groups. This finding is highly disconcerting (D. Hodge, personal communication, October 2, 2015) as social workers make up the largest proportion of mental health workers in the U.S. (Substance Abuse and Mental Health Services Administration, 2010, p. 158). Results from a study by Oxhandler, Parrish, Torres, and Achenbaum (2015) found that over half of licensed clinical social workers felt trained and efficacious about integrating religion and spirituality into practice, yet only $13 \%$ had taken a formal course on the subject matter. Further, those with intrinsic religiosity and training in religion and spirituality felt more positively towards integration within clinical social work. Thus training is a key component in both shaping attitudes and equipping practitioners towards integrative practice. Oxhandler et al. (2015) also noted less than half of the licensed clinical social workers referred clients to religious and spiritual resources even when the majority were open to doing so. Thorpe (2001) reported that $39.4 \%$ of participants in her study avoided discussing spiritual and religious content with clients, and students perceived minimal coursework on such material. "Social work students should be 
further educated regarding the importance of integrating RS into their psychosocial assessments and how to link clients to community resources that address these needs if they are identified" (Oxhandler, Parrish, Torres, \& Achenbaum, 2015, p. 235). Hodge, Bauman, and Cummings (2006) examined social work textbooks citing the foundational role curricular choices play in molding attitudes of the profession. Alarmingly, they found that evangelical Christians and Muslims were "essentially invisible" (p. 218) and little mention was made of spirituality versus religion in comparison to other multicultural categories. Further, the portrayal of evangelical Christians was often negative. As a result, Hodge et al. (2006) indicated how stereotypes and prejudice flourish under such circumstances.

Lastly, scores on the SARCA did correlate and predict scores on the SCS-R-II, which indicate both instruments measure similar factors regarding competence in addressing spiritual and religious issues in counseling. These findings support use of the SARCA and SCS-R-II in mental health graduate institutions and for practitioners in the field.

\section{Limitations of the Study}

The primary limitation of this study involved defining the constructs of religion and spirituality. As each may take on a different meaning for participants, accurately evaluating competent spiritual integration in counseling remains somewhat abstract. This study set forth definitions for participants, but individual interpretation and comprehension are ongoing challenges.

The disproportionately higher number of counseling and social work students versus psychology graduate students may not be a representative sample of mental health trainees, thus may be attributed to a sampling error and adds caution in generalizing results. However, a recent report by the U.S. Department of Health and Human Services (HHS), Health Resources and Services Administration (HRSA), and the National Center for Health Workforce Analysis (2013) estimated psychologists number least among the three behavioral health occupations. Even still, the participant ratios did not mirror these cited statistics. Further, all subjects attended accredited institutions (by APA, CACREP, and CSWE), so may not represent mental health graduate students at non-accredited schools or those in the process of receiving accreditation. This selection bias negates the larger pool, which would then extend to more religiously affiliated schools that have chosen not to pursue secular accreditation, thereby constraining their program faculty, philosophy and curriculum (P. Monroe, personal communication, October 13, 2015). Response bias may have played a role in this study in that primarily those interested in the subject matter participated. Social desirability bias was another potential influence on responses; however, the survey was anonymous thus minimizing any effect. Other limitations included a predominantly female, Caucasian participant 
pool, which primarily consisted of a Christian (Catholic and Protestant) background, and the self-report nature of the instrumentation. These factors may diminish the overall generalizability of the study.

\section{Implications for Counselor Education and Clinical Training}

The findings of this study indicate that significant progress has been made in enhancing religious and spiritual integration within mental health graduate institutions, yet considerably more attention is placed upon other multicultural aspects in training and instruction over spirituality and religion (Hodge, Baughman, \& Cummings, 2006). Counseling and psychology students met the cutoff score for competence according to the SCS-R-II (Robertson, 2011) and also scored higher on the SARCA (Fluellen, 2007). Social work students were not too far behind. However, students at non-religious affiliation schools scored lowest. The resulting implication would promote use of these measures in said institutions to evaluate competence levels for counseling, psychology, and social work students. Further, program assessments specifically aimed at how spiritual and religious integration is taught would prove beneficial. If these deficits remain unaddressed, client care is compromised. Therefore, new standards by governing bodies may be an avenue for accountability, development, and growth.

Directors and professors at non-religiously affiliated graduate schools of mental health may seek to evaluate what classes attend to spiritual and religious integration in counseling. Although practitioners and students both assert that spirituality is an important component to address in all stages of counseling (Cashwell et al., 2007; Shafranske and Malony, 1990; Young, Cashwell, Wiggins-Frame, \& Belaire, 2002), ongoing research points to the lack of consistency, curriculum, and emphasis regarding specific interventions utilizing spirituality within sessions (Adams, 2012; Brown, Carney, Parrish, \& Klem, 2013; Burke et al., 1999; Carlson et al., 2014; Cashwell et al., 2013; Furness \& Gilligan, 2010; Gonsoriek et al., 2009; Moreira-Almeida et al., 2014; Murphy et al., 2006; Oxhandler \& Pargament, 2014; Russell \& Yarhouse, 2006; Walker, Gorsuch, \& Tan, 2004; Young et al., 2002). Further, courses vary by instructor and content with regard to inclusion of spirituality and religion (Robertson, 2010; Young et al., 2002) in various mental health programs. Another implication would involve a standardized curriculum for teaching and training integrating spirituality and religion within counseling for the various mental health graduate institutions to adapt accordingly. Oxhandler et al. (2015) suggested some form of standardized continuing education for social workers. Such a document describing key practices, assignments, projects, and lectures provides a foundation for professors to modify and subsequently utilize in the classroom. Perhaps CACREP, APA, and the CSWE would consider adding specific standards for enhanced accountability. In the same vein, Reiner and 
Dobmeier (2014) recommended ASERVIC leaders lobby CACREP in order "to ensure that spirituality concepts are more pronounced in the core and program area standards" (p. 205) and work with the National Board for Certified Counselors (NBCC) to include spirituality on the National Counselor Exam. Carrington (2010) supports such formalization for social work training too. Since the completion of this study, CACREP (2016) includes instruction on spirituality within multicultural and addiction courses, but excludes terminology on religion. Perhaps greater emphasis on constructs within religion as distinct from spirituality may increase students' competence.

By increasing spiritual integration competence among mental health graduate students, practitioners will be better positioned to attend to diverse client needs surrounding belief systems, values, and worldviews. With the abundance in literature supporting the benefits of such inclusion, program directors and supervisors cannot neglect calling greater attention to incorporation within curricular development and training protocol (Allen \& Wozniak, 2014; Cashwell \& Young, 2011; Chandler, Holden, \& Kolander, 1992; Fincham, Stanley, \& Beach, 2007; Hook et al., 2010; Knabb, 2014; Koenig, George, \& Titus, 2004; Larson \& Wilson, 1980; Larson et al., 1992; Miller \& Thoresen, 2003; Purdy \& Dupey, 2005; Sullivan, 2001).

\section{Recommendations for Future Research}

Future studies may specifically examine how Christian mental health programs teach integration of spirituality and religion within counseling and also compare Christian schools, which have specific accreditation versus those that do not on these same measures utilized in this research (SCS-R-II and SARCA). In addition, a qualitative study would enhance the literature on how students perceive such coursework and training in both religiously affiliated and non-affiliated graduate schools. Another study utilizing a correlational study comparing Hodge's Spiritual Competence Scale (SCS; 2007) with the SCS-R-II would aid in understanding how programmatic perception on spirituality and religion affects competence with integration in practice. As a result, comparing differences in Christian and non-religiously affiliated schools regarding said evaluation provides empirical evidence on how critical faculty attitudes towards religion and spirituality influence student achievement. Additionally, a correlational study comparing the SCSR-II and the SARCA with the Religious/Spiritually Integrated Practice Assessment Scale (RSIPAS; Oxhandler \& Parrish, 2014) to determine convergent validity would distinguish which measures may work best in various settings.

\section{Conclusion}

This study's findings serve to further the research on spirituality and religion within mental health education and training. The quantitative evidence provided 
is significant in distinguishing between schools with religious affiliation versus no affiliation with regard to competently integrating spirituality and religion within counseling based upon the SARCA and SCS-R-II. Counseling graduate students outperformed psychology and social work students on both instruments, but without statistical significance. Trainees who very strongly identified with their religion and spirituality were significantly more competent to integrate these topics into therapy. Clearly, spirituality and religion deserve increased attention in the helping profession. Thus graduate schools ought to place greater emphasis on spiritual development models, distinguishing the two constructs of religion and spirituality, conducting valid spiritual assessments and interventions, increase time spent discussing spirituality and religion in supervision, examining biases, and measuring competence with valid, reliable instrumentation, two of which were utilized in this study.

\section{References}

Adams, C. M. (2008). The graduate training of counselors in religious and spiritual competency. (Doctoral dissertation, State University of New York, Buffalo, New York). Retrieved from Academic Search Complete.

Allen, K. N., \& Wozniak, D. F. (2014). The integration of healing rituals in group treatment for women survivors of domestic violence. Social Work in Mental Health, 12, 52-68. doi: $10.1080 / 15332985.2013 .817369$

Allen, S., \& Crouch, A. (2005). Cultural and spiritual health assessment. Retrieved from https://www.blackwellpublishing.com/content/BPL_Images/Content_store/Sample_ chapter/9781405114585/9781405114585_4_010.pdf

American Counseling Association (ACA). (2014). Code of ethics. Alexandria, VA: Author.

American Psychological Association (APA). (2010). Ethical principles of psychologists and code of conduct. Retrieved from www.apa/org/ethics/code.html

Association of Spiritual, Ethical, and Religious Values in Counseling (ASERVIC). (2005, 2009). Competencies for integrating spirituality into counseling. Alexandria, VA: Author.

Barker, S. L. (2007). The integration of spirituality and religion content in social work education: Where we've been, where we're going. Social Work \& Christianity, 34, 146-166.

Barnes, L., Plotnikoff, G., Fox, K., \& Pendleton, S. (2000). Spirituality, religion, and pediatrics: Intersecting worlds of healing. Pediatrics, 106(suppl), 899-908.

Barrett, D., Kurian, G., \& Johnson, T. (2001). World Christian encyclopedia: A comparative survey of churches and religions in the modern world ( $2^{\text {nd }}$ ed.). New York, NY: Oxford University Press.

Bernard, J., \& Goodyear, R. (2009). Fundamentals of clinical supervision (4 ${ }^{\text {th }}$ ed.). Upper Saddle River, NJ: Pearson.

Bilgrave, D. P., \& Deluty, R. H. (1998). Religious beliefs and therapeutic orientations of clinical and counseling psychologists. Journal for the Scientific Study of Religion, 37, 329-349.

Brown, D. R., Carney, J. S., Parrish, M. S., \& Klem, J. L. (2013). Assessing spirituality: The relationship between spirituality and mental health. Journal of Spirituality in Mental Health, 15, 107-122. doi: 10.1080/193494637.2013.776442 
Burke, M. T., Hackney, H., Hudson, P., Miranti, J., Watts, G. A., \& Epp, L. (1999). Spirituality, religion, and CACREP curriculum standards. Journal of Counseling \& Development, 77, 251-257.

Carlson, T. S., McGeorge, C. R., \& Toomey, R. B. (2014). Establishing the validity of the Spirituality in Clinical Training Scale: Measuring the level of integration of spirituality and religion in family therapy training. Contemporary Family Therapy, 36, 310-325. doi: 10.1007/s10591-013-9278-y

Cashwell, C. S., Bentley, D. P., \& Bigbee, A. (2007). Spirituality and counselor wellness. Journal of Humanistic Counseling, Education and Development, 46, 66-81.

Cashwell, C. S., \& Young, J. S. (Eds). (2011). Integrating spirituality and religion into counseling: A guide to competent practice ( $2^{\text {nd }}$ ed.). Alexandria, VA: American Counseling Association.

Cashwell, C. S., Young, J. S., Fulton, C. L., Willis, B. T., Giordano, A., Daniel, L. W., Crockett, J., Tate, B. N., \& Welch, M. L. (2013). Clinical behaviors for addressing religious/spiritual issues: Do we practice what we preach? Counseling and Values, 58, 45-58. doi: 10.1002/j.2161007X.2013.00024.X

Cates, K. A. (2009). Counselor spiritual competencies: An examination of counselor practices. (Doctoral dissertation, Auburn University, Auburn, Alabama). Retrieved from Academic Search Complete.

Chandler, C. K., Holden, J. M., \& Kolander, C. A. (1992). Counseling for spiritual wellness: Theory and practice. Journal of Counseling \& Development, 71, 168-175.

Cheston, S. E., \& Miller, J. L. (2011). The use of prayer in counseling. In C. S. Cashwell \& J. S. Young (Eds.), Integrating spirituality and religion into counseling: A guide to competent practice ( $2^{\text {nd }}$ ed., pp. 243-260). Alexandria: VA: American Counseling Association.

Cloninger, C. R. (2006). Fostering spirituality and well-being in clinical practice. Psychiatric Annals, 36(3), 1-6.

Cohen, J. (1988). Statistical power analysis for the behavioral sciences (2nd ed.). Hillsdale, NJ: Lawrence Erlbaum Associates.

Council for Accreditation of Counseling and Related Educational Programs [CACREP]. (2009). 2009 standards for accreditation. Alexandria, VA: Author.

Council for Accreditation of Counseling and Related Educational Programs [CACREP]. (2016). 2016 standards for accreditation. Alexandria, VA: Author.

Crook-Lyon, R. E., O’Grady, K. A., Smith, T. B., Jensen, D. R., Golightly, T., \& Potkar, K. A. (2012). Addressing religious and spiritual diversity in graduate training and multicultural education for professional psychologists. Psychology of Religion and Spirituality, 4, 169-181. doi: $10.1037 / \mathrm{a} 0026403$

Dailey, S. F., Gill, C. S., \& Robertson, L. A. (2015). Spiritual Competency Scale: Further analysis. Measurement and Evaluation in Counseling and Development, 48, 15-29. doi: $10.1177 / 0748175614544688$

Fincham, F. D., Stanley, S. M., \& Beach, S. H. (2007). Transformative processes in marriage: An analysis of emerging trends. Journal Of Marriage \& Family, 69(2), 275-292. doi:10.1111/ j.1741-3737.2007.00362.x

Fluellen, S. J. (2007). Development of the Spiritual and Religious Competency Assessment (SARCA): An instrument to measure competency in supervisees (Doctoral dissertation). Available from ProQuest Dissertations and Theses database. (UMI No. 3291350)

Frankl, V. (1955). The doctor and the soul: An introduction to logotherapy. Chicago, IL: University of Chicago Press. 
Furman, L. D., Benson, P. W., \& Canda, E. R. (2008). The integration of religions and spirituality into social work practice and education. US Executive Report, 1-13. Retrieved from www. spiritualityreligionsurvey.com/Documents/2008\%20US\%20Executive\%20Report.pdf

Furness, S., \& Gilligan, P. (2010). Social work, religion and belief: Developing a framework for practice. British Journal of Social Work, 40, 2185-2202. doi: 10.1093/bjsw/bcp159

Gallup. (2014). Religion in America. Retrieved from www.gallup.com/poll/1690/Religion.aspx

Garzon, F., Worthington, E. L., Jr., Tan, S. Y., \& Worthington, R. K. (2009). Lay Christian counseling and client expectations for integration in therapy. Journal of Psychology and Christianity, 28, 113-120.

Gonsoriek, J. C., Richards, P. S., Pargament, K. I., \& McMinn, M. R. (2009). Ethical challenges and opportunities at the edge: Incorporating spirituality and religion into psychotherapy. Professional Psychology: Research and Practice, 40(4), 385-395. doi: 0.1037/a001648

Hodge, D. R. (2000). Spiritual ecomaps: A new diagrammatic tool for assessing marital and family spirituality. Journal of Marital and Family Therapy, 26, 217-228. doi: 10.1111/j.17520606.2000.tb00291.x

Hodge, D. R. (2007). The Spiritual Competence Scale: A new instrument for assessing spiritual competence at the programmatic level. Research on Social Work Practice, 17, 287-195.

Hodge, D. R., \& Limb, G. E. (2010). Conducting spiritual assessments with Native Americans: Enhancing cultural competency in social work practice courses. Journal of Social Work Education, 46, 265-284. doi: 10.5175/JSWE_2010.200800084

Hodge, D. R., Baughman, L. M., \& Cummings, J. A. (2006). Moving toward spiritual competency. Journal of Social Service Research, 32, 211-231. doi: 10.1300/J079v32n04_12

Hook, J. N., Worthington, E. L., Jr., Davis, D. E., Jennings, D. J., II, Gartner, A. L., \& Hook, J. P. (2010). Empirically supported religious and spiritual therapies. Journal of Clinical Psychology, 66, 46-72. doi: $10.1002 /$ jclp. 20626

Horvath, A. O., \& Luborsky, L. (1993). The role of the therapeutic alliance in psychotherapy. Journal of Consulting and Clinical Psychology, 61, 561-573.

Hull, C. E., Suarez, E. F., Sells, J. N., \& Miller, M. M (2013). Addressing spiritual dialogue in supervision: Comparing supervisor and supervisee perceptions. Journal of Psychology \& Christianity, 32, 30-42.

Knabb, J. J. (2014). A preliminary investigation of the relationship between religion and marital adjustment among Christian adults from a conservative denomination. Journal of Psychology \& Christianity, 33, 263-276.

Knox, S., Catlin, L., Casper, M., \& Schlosser, L. Z. (2005). Addressing religion and spirituality in psychotherapy: Clients' perspectives. Psychotherapy Research, 15, 287-303. doi: 10.1080/10503300500090894

Koenig, H. G., George, L. K., \& Titus, P. (2004). Religion, spirituality, and health in medically ill hospitalized older patients. Journal of the American Geriatrics Society, 52, 554-562. doi: 10.1111/j.1532-5415.2004.52161.x

Larson, D. B., Sherrill, K.A., Lyons, J. S., Craigie, F. C., Jr., Thielman, S. B., Greenwold, M. A., \& Larson, S. S. (1992). Associations between dimensions of religious commitment and mental health reported in the American Journal of Psychiatry and Archive of General Psychiatry: 19781989, American Journal of Psychiatry, 149(4), 557-559.

Larson, D. B., \& Wilson, W. P. (1980). Religious life of alcoholics. Southern Medical Journal, 73, 723-727. 
Mahoney, A., Pargament, K., Jewell, T., Emery, E., Scott, E., Swank, E., Rye, M., \& Butter, E. (1997, August). Sacred vows: The sanctification of marriage and its psychosocial implications. Paper presented at the American Psychological Association, Chicago.

Miller, W. R., \& Thoresen, C. E. (2003). Spirituality, religion, and health: An emerging research field. American Psychologist, 58, 24-35.

Moreira-Almeida, A., Koenig, H. G., \& Lucchetti, G. (2014). Clinical implications of spirituality to mental health: review of evidence and practical guidelines. Revista Brasileira de Psiquiatria, 36, 176-182. doi: 10.1590/1516-4446-2013-1255

Murphy, M. J., Park, J., \& Lonsdale, N. J. (2006). Marriage and family therapy students' change in multicultural counseling competencies after a diversity course. Contemporary Family Therapy, 28, 303-311. doi: 10.1007/s10591-006-9009-8

Myers, J. E., \& Williard, K. (2003). Integrating spirituality into counseling and counselor training: A developmental, wellness approach. Counseling \& Values, 47, 142-155.

Oxhandler, H. K., \& Pargament, K. I. (2014). Social work practitioners' integration of clients' religion and spirituality in practice: A literature review. Social Work, 59, 271-279. doi: 10.1093/sw/swu018

Oxhandler, H. K., \& Parrish, D. E. (2014). The development and validation of the Religious/ Spiritually Integrated Practice Assessment Scale. Research on Social Work Practice. Advance online publication. doi: 10.1177/1049731514550207

Pargament, K. I. (1999). The psychology of religion and spirituality? Yes and no. International Journal of Psychology of Religion, 9, 3-16.

Pelletier, A. L., \& McCall, J. W. (2005). A modular curriculum for integrating spirituality and health care. New Directions For Teaching \& Learning, 104, 51-58.

Pentaris, P. (2012). Religious competence in social work practice: The UK picture. Social Work \& Society, 10(2), 1-4. Retrieved from http://www.academia.edu/3093824/Religious_competence_ in_social_work_practice_The_UK_picture

Pew Research Center. (2015). America's changing religious landscape. Retrieved from www. pewforum.org/2015/05/12/americas-changing-religious-landscape/

Purdy, M., \& Dupey, P. (2005). Holistic Flow Model of Spiritual Wellness. Counseling and Values, 49, 95-106.

Ratts, M. J., Singh, A. A., Nassar-McMillan, S., Butler, S. K., \& McCullough, J. R. (2015). Multicultural and social justice counseling competencies. Alexandria, VA: AMCD.

Reiner, S. M., \& Dobmeier, R. A. (2014). Counselor preparation and the Association for Spiritual, Ethical, and Religious Values in Counseling Competencies: An exploratory study. Counseling \& Values, 49, 192-207. doi: 10.1002/j.2161-007X.2014.00051.x

Reuder, M. E. (1999). A history of Division 36 (Psychology of Religion). In D. A. Dewsbury (Ed.), Unification through division: Histories of the divisions of the American Psychological Association (Vol. 4, pp. 91-108). Washington, DC: American Psychological Association.

Richards, P. S., \& Bergin, A. E. (1997). A spiritual strategy for counseling and psychotherapy. Washington, DC: American Psychological Association.

Richards, P. S., Bartz, J. D., \& O'Grady, K. A. (2009). Assessing religion and spirituality in counseling: Some reflections and recommendations. Counseling and Values, 54, 65-79.

Robertson, L. A. (2008). The Spiritual Competency Scale: A comparison to the ASERVIC spiritual competencies (Doctoral dissertation). Available from ProQuest Dissertations and Theses database. (UMI No. 3341000) 
Robertson, L. A. (2010). The Spiritual Competency Scale. Counseling and Values, 55, 6-24.

Robertson, L. A. (2011). The Revised Spiritual Competency Scale II. Provided by author in personal communication.

Russell, S. R., \& Yarhouse, M. A. (2006). Training in religion/spirituality within APA-accredited psychology predoctoral internships. Professional Psychology: Research and Practice, 37, 430436. doi: $10.1037 / 0735-7028.37 .4 .430$

Rye, M. S. (2005). The religious path toward forgiveness. Mental Health, Religion \& Culture, 8(3), 205-215. doi: 10.1080/13694670500138882

Shafranske, E. P., \& Malony, H. N. (1990). Clinical psychologists' religious and spiritual orientations and their practice of psychotherapy. Psychotherapy, 27, 72-78.

Sue, D., Arredondo, P., \& McDavis, R. J. (1992). Multicultural counseling competencies and standards: A call to the profession. Journal of Multicultural Counseling \& Development, 20, 64-89.

Sullivan, K. T. (2001). Understanding the relationship between religiosity and marriage: An investigation of the immediate and longitudinal effects of religiosity on newlywed couples. Journal of Family Psychology, 15, 610-626.

Tan, P. P. (2005). The importance of spirituality among gay and lesbian individuals. Journal of Homosexuality, 29, 134-144. doi: 10.1300/J082v49n02_08

Thorpe, S. P. (2001). Students' perceptions of competency in providing spiritually sensitive services. (Master's thesis, California State University, Long Beach, California). Retrieved from Academic Search Complete.

U.S. Department of Health and Human Services, Health Resources and Services Administration, National Center for Health Workforce Analysis. (2013). The U.S. health workforce chartbook. Rockville, MD: the National Center. Retrieved from

Walker, D. F., Gorsuch, R. L., \& Tan, S. Y. (2004). Therapists' use of religious and spiritual interventions in Christian counseling: A preliminary report. Counseling and Values, 49, 107-119.

Wombles, K. (2010, May 28). A brief history of the psychology of religion. Science 2.0: Join the revolution. Retrieved from http://www.science20.com/science_autism_spectrum_disorders/ brief_history_psychology_religion.

Young, J. S., Cashwell, C. S., Wiggins-Frame, M., \& Belaire, C. (2002). Spiritual and religious competencies: A national survey of CACREP-accredited programs. Counseling and Values, 47, 22-33.

Zinnbauer, B. J., \& Pargament, K. I. (2000). Working with the sacred: Four approaches to religious and spiritual issues in counseling. Journal of Counseling \& Development, 78, 162-171. 